\title{
Fire Situations and Prevention Measures of residential building
}

\section{Baixia Zhou}

Public Security Fire Forces College, Kunming 650208, China.

\begin{abstract}
The proportion of residential building is the largest in all buildings. With the development of urbanization, residential building fires are at high momentum. The paper lists the residential building fires and the number of casualties' proportion to total fires from 2011 to 2014, analyzing the high incidence causes of the fires and casualties and putting forward suggestions and countermeasures including carrying out fire safety education to improve the fire safety awareness of residents, fulfilling responsibility to enhancing fire safety management capabilities, perfecting fire apparatus to develop fire safety environment and enhancing public awareness of fire safety, equipping evacuation equipments to promote response ability to deal with disasters etc.
\end{abstract}

Keywords. fire safety, residential building, the number of fires, fire casualties.

\section{Foreword}

Family is the most basic unit of the society, and family peace and harmony will bring about social harmony and stability. But the sudden fire accidents always endanger the residential buildings, affecting people's lives and property safety. Especially, with the rapid development of economy and society and the acceleration of urbanization in our country, there are more and more urban residential construction with growing volume and larger height. While some places do not attach importance to the fire safety of residential buildings, leading to prominent fire hazards. In addition, residents of our country generally have weak awareness of fire safety, so the residential building fire safety situation is not optimistic. In recent years, residential building fire has been at a high incidence, and the number of fire, personnel injury, death and other indicators of fire account for a rather high proportion to total fires. Table 1 shows the residential building fires number's proportion to total fires from 2011 to 2015 [1-3].

Table 1 The residential building fires number's proportion to total fires from 2011 to 2014

\begin{tabular}{|c|c|c|c|c|c|}
\hline Year & $\begin{array}{c}\text { Total number of } \\
\text { fires }\end{array}$ & $\begin{array}{c}\text { Number of } \\
\text { residential building } \\
\text { fires }\end{array}$ & $\begin{array}{c}\text { Number of fires in education, } \\
\text { office, public gathering places }\end{array}$ & $\begin{array}{c}\text { Number of traffic } \\
\text { fires }\end{array}$ & $\begin{array}{c}\text { Number of industrial } \\
\text { building fires }\end{array}$ \\
\hline 2011 & 125,000 & 48,500 & 12,000 & 13,000 & 26,000 \\
\hline 2012 & 152,000 & 46,000 & 28,000 & 15,300 & 13,500 \\
\hline 2013 & 388,000 & 117,000 & 26,100 & 35,300 & 20,400 \\
\hline
\end{tabular}




\begin{tabular}{|l|l|l|l|l|l|}
\hline 2014 & 395,000 & 142,000 & 21,100 & 35,700 & 24,200 \\
& & & & & \\
\hline
\end{tabular}

In the process of social and economic construction, especially in the process of urban construction and development, we do not pay attention to the fire safety of residential buildings, resulting in a low degree of standardization and scientification of fire prevention in residential buildings and frequent residential building fires. Not only the number of fires is large, but also the proportion of injuries and deaths caused by residential building fires are at a high level. Table 2 shows the proportion of residential building fire casualties to total fires in the past four years [1-3].

Table 2 The comparison of fire casualties of residential building fires and other building fires

\begin{tabular}{|c|c|c|c|c|}
\hline Year & Residential building & Assembly occupancies & $\begin{array}{c}\text { Production warehouse } \\
\text { buildings }\end{array}$ & Others \\
\hline 2011 & 787 people, $71 \%$ & 156 people, $14.1 \%$ & 70 people, $6.3 \%$ & 95 people, $8.6 \%$ \\
\hline 2012 & 732 people, $71.2 \%$ & 152 people, $14.8 \%$ & 83 people, $8.1 \%$ & 61 people, $5.9 \%$ \\
\hline 2013 & 1429 people, $67.6 \%$ & 311 people, $14.7 \%$ & 262 people, $12.4 \%$ & 111 people, $5.3 \%$ \\
\hline 2014 & 1244 people, $70 \%$ & 307 people, $17 \%$ & 130 people, $7 \%$ & 108 people, $6 \%$ \\
\hline
\end{tabular}

As can be seen from table 2, residential building fires, with a greater impact, are more likely to endanger the lives of people than other buildings. Therefore, residential building fire safety cannot be ignored.

\section{The main reasons for the large number of fires and more residential building fire casualties in China}

In order to effectively prevent and curb resident fires, create a safe and harmonious living environment, to ensure the safety of the lives and property of residents, it is necessary to analyze the main reasons for the large number of urban residential building fires and increasing resulting casualties in China.

\subsection{Weak awareness of fire prevention of urban residents in China}

Due to the lack of the national fire safety education and not widespread popularization of fire science popularization, insufficient awareness of the importance of urban residents on fire safety, people do not attach importance to or do not have the opportunity to learn fire safety knowledge, unable to use the fire-fighting equipment and do not know how to escape in case of fire5 [4]. Some residents still connect wires randomly, throw about cigarette butts and irregularly use fire, electricity and gas in daily life; some residents use a lot of flammable combustible materials in the process of home decoration, which increases the fire load; some residents store excessive hazardous chemicals at home; and some residents set off fireworks and firecrackers in the residential areas at any time, directly leading to the residential building fires. It will raise the proportion of casualties of residential building fires which are composed of vulnerable groups such as the elderly and children at home who have poor ability to dispose of the fire and escape.

\subsection{Low level of fire safety management in urban residential areas in China}

Some of urban residential quarters in the management mode of government, sub-district office, neighborhood committee, enterprise, etc. have weak awareness of the importance of fire prevention; some of residential quarters not only fail to include fire prevention publicity in the daily routine, even do not carry out fire control propaganda activities during the safety month and on 119 fire awareness day; some of residential quarters do not carry out fire safety management in accordance with the provisions of the fire law, fail to implement fire safety responsibility system or establish fire organizations as required, let alone extend the network of fire services organizations to the residents group, residential 
units and small business outlets so that the residential areas are lack of organized, scientific, normative fire safety management in the daily life. As for the residential quarters under the unified management of property management companies, since the property management fee does not cover the funds for daily operation, maintenance and update of fire facilities, fire facilities and equipment used are not regularly maintained, tested and replaced. In some communities, the security personnel are changed frequently, while the new personnel have not been trained in fire safety, do not know what is the automatic fire control facilities and unable to operate automatic fire facilities. They cannot quickly start the internal self fire protection facilities to control fire at the initial stage, which delays in fire fighting, causing a low flame spread to a fire hazard [5].

\subsection{Bad situation of fire safety of high-rise residential buildings in China}

With the rapid development of economic construction and the continuous increase of urban population, high-rise residential buildings are increasing. At present, China's public security fire control institutions attach more importance to monitor and manage public buildings instead of high-rise residential buildings. However, for high-rise residential buildings, the fire spreads fast inside the shaft, and it is difficult to evacuate the old and children left at home in case of fire. Besides, since complicated partition inside the residential buildings increases the difficulty of fire fighting and rescue, it is easy to cause major disasters. In recent years, many high-rise residential building fires occurred in China. At 15:23 on September 22, 2015, a fire broke out in the house on the $13^{\text {th }}$ floor of a 33-storey residential building in Urban Garden on Shucheng Road, Luohu District, Shenzhen. The flame was as high as the height of 3 storeys and the fire quickly spread to some houses on the $15^{\text {th }}, 16^{\text {th }}$ and $17^{\text {th }}$ floors. On November 15, 2010, a fire occurred in a 28 -storey teacher's apartment at No. 728, Jing'an District, Shanghai due to irregular welding in heat preservation construction on outside wall, resulting in 58 deaths and 71 injuries. In recent years, the continuous occurrence of high-rise residential building fire is an alarm to the whole society.

\subsection{Poor urban residential building fire infrastructure construction in China}

In China, there were no strict requirements on the building fire protection infrastructure by related fire prevention specifications and regulations during their construction since some old urban residential buildings were built earlier, which results in the deficiency of fire fighting hardware facilities. Some of the old residential buildings are surrounded by newly developed markets with dead ends and narrow entry roads, which obstructs the fire fighting truck to rescue closely; some of the old residential buildings have no fire water and outdoor fire hydrants; some of the residential quarters occupy the fire separation and set up temporary places between buildings with combustible materials for community management; in some of the residential quarters, private cars are parked casually, blocking the fire fighting access and occupying safety evacuation site [6]. In other newly built urban residential quarters under the unified planning of the government with property and security management, the personnel are unable to use fire infrastructure according to codes.

\section{Prevention countermeasures of frequent fires in residential buildings}

It can be seen from fire data in Table 1 and 2 that the proportion of the number of residential building fires and resulting casualties is held at the highest level. Residential building fire not only is related to the safety of each family, but also it is easy to bring disaster the neighbors and cause the civil disputes, affecting social stability. How to do a good job of fire safety management of residential buildings to curb the frequent occurrence of fire in residential buildings is an important task in front of us.

\subsection{Carrying out fire safety education to improve the fire safety awareness of residents}

To enhance residents' awareness of fire safety is an effective way to prevent the occurrence of residential building fires. Neighborhood committee and property management and service departments should carry out rich and colorful fire 
control propaganda activities close to people's lives by dint of corridors and public places, such as setting up fire publicity windows inside the residential quarter, putting up fire warning signs in the building corridors to create a fire propaganda atmosphere. Some newly built residential areas in good condition can use modern facilities to propagandize, for example, use the unit LED screen to send fire safety knowledge, carry out fire control propaganda and education targeted at the vulnerable groups such as children and the elderly taking advantage of amusement room for children and activity room for the elderly. Meanwhile, the neighborhood committee and property management and security department should carry out targeted fire safety education activities in different holidays and seasons, like publicity of outdoor paper offerings burning on Tomb-sweeping Day, setting off fireworks before the Spring Festival, fire safety education to the youth during winter and summer vacation.

\subsection{Fulfilling responsibility to enhancing fire safety management capabilities}

Neighborhood committee and property security department should, according to the provisions of Fire Protection Law and Decree No. 61 of the Ministry of Public Security, clarify fire management responsibilities, set up fire safety organizations in the residential quarter, regularly inspect fire protection of electricity and gas using, regularly carry out fire-watch of fire-fighting equipment inside the unit, guide the residents in some of the residential quarters who block escape way by installing burglar mesh on the balcony and windows, dissuade those who park their bikes or stack waste furniture, packaging boxes on the platform and in the staircase or even clear up forcefully, mark out the areas for parking motor vehicles to prevent them from containing fire hydrants and blocking the fire passage, and strict manage residential buildings with commercial serving cubbies set on the ground floor according to relevant public building provisions [7].

\subsection{Perfecting fire apparatus to develop fire safety environment}

According to the requirements of Fire Law, fire cistern, fire pumps, outdoor hydrant system and other public fire-fighting installations should be set in the residential quarter; fire extinguishers, indoor fire hydrants and other fire extinguishing equipment should be outfitted in the units; sufficient fire separation, fire fighting access and safe evacuation site should be reserved between buildings. For some old residential quarters being short of fire-fighting equipment, the neighborhood committee should seek for the fund support of superior competent department and sub-district office to buy necessary fire hose, gun and fire extinguishers, etc. to improve fire safety situation [8]. For newly built residential quarters, fire infrastructure should be included in the construction of residential buildings, and fire passage should be planned at the same time to ensure that fire engines can put out the fire closely, and fire separation should be reserved to ensure that the flame will not be spread to other buildings. In the meanwhile, fire resistance rating and fire separation should be ensured to meet the specification.

\subsection{Equipping evacuation equipments to promote response ability to deal with disasters}

The newly revised Code for Fire Protection Design of Buildings was implemented in May 2015, adding the residential building fire protection design and explicitly stipulating fire resistance rating, fire separation, safety evacuation and evacuation range, etc. of the buildings. In addition to following normative design, new type of fire control products and technologies should be vigorously promoted in the newly built residential buildings, such as installing smoke type fire automatic detection alarm at home, gas leakage alarm and control system in the kitchen, simply-equipped automatic sprinkler system using the pressure of tap water and other facilities to automatically detect and put out the fire. Some families can also be equipped with fire extinguishers, household evacuation gas masks, fire blankets and other equipment [9]. With the development of the Internet of things technology in our country, a number of high-grade residential areas with the installation of digital security monitoring system can transmit the fire information to the safety monitoring data, helping property management company or security monitoring center find and deal with the fire instantly. 


\section{Conclusion}

Residential building plays an important role in urban construction, and it is an important place for urban residents to live and engage in various activities. Frequent occurrence of residential building fires will seriously affect our people's lives. Therefore, it is necessary to strengthen the supervision of fire safety of residential buildings for timely detection and elimination of fire hazards; it is necessary to improve the residents' awareness of fire safety so as to prevent and reduce the occurrence of fire; it is necessary to perform a more rigorous residential building fire safety design in accordance with Code for Design of Building Fire Protection newly revised in 2015 to improve residential building fire resistance; it is necessary to perfect the construction of fire infrastructure in the residential quarters according to the new specification to improve the ability to control the initial fire, and to make efforts to promote the application of new fire alarm, fire fighting and escape equipment in the household so as to enhance the ability to respond to fire and ensure residents' personal and property security.

\section{References}

1. Yu Jianhua, China Fire Fighting Yearbook 20120, Beijing, China Personnel Publishing House, December 2012.

2. Yu Jianhua, China Fire Fighting Yearbook 20130, Beijing, China Personnel Publishing House, December 2013.

3. Yu Jianhua, China Fire Fighting Yearbook 20140, Kunming, Yunnan People's Publishing House, December 2014.

4. Chen Peng, Wang Da, Problems and Countermeasures of Fire Safety in Urban Residential Quarters, Fire Safety Journal, 2011 (1), 65-68.

5. Wang Yingjun, Strengthen Community Fire Prevention Work to Prevent Urban Residents Fire, Journal of Guangxi Teachers Education University (Philosophy and Social Science Edition), 2004 (6), 144-146.

6. Shi Haifeng, Main Problems and Countermeasures of Residents' Fire Prevention, Journal of Changzhou University (Social Science Edition), 2011 (4), 33-35.

7. Wang Li, Fire Safety Problems and Solutions in Residential Quarters, Jiangxi Building Materials, 2014 (20), 296-298.

8. Li Qinggong, Wu Dong, Xie Fei, Song Wenhua, Analysis on Residential Fire Hazard and Safety Protection Measures, Fire Science and Technology, 2009 (6), 457-460.

9. Wang Hui, Yuan Kexia, Study on Fire Safety Management of Residential Property, Science and Technology in Western China, 2014 (6), 93-95. 